\title{
Gastronomic Reflections of Cittaslow Movement on Local Cuisine: The Case Study of Seferihisar (İzmir, Turkey)
}

\author{
Onur Görkem*, Yüksel Öztürk** \\ Received: January 2014 | Accepted: March 2014
}

\begin{abstract}
Globalization is forcing people to work harder, to live faster, to produce more and to consume more. The eating habits of people such as their lifestyles are affected by these pressures, and lose its cultural authenticity. People to get rid of this whirlpool who fall into it, come together, are looking for remedies and generate various reaction groups. Slow food and cittaslow movements are the most common and effective formations, being said about. This study was carried out to determine the assessments of people who live in Seferihisar town of İzmir as the first cittaslow in Turkey, regarding the cittaslow movement's effects on gastronomy. In the study, different dimensions of the gastronomic effects of Seferihisar slow city constitution have been considered. According to the data obtained from surveys, cittaslow movement reflected positively on local cuisine and eating habits of the people, but found to be caused an increase in the price of food and beverage. Local people's different ethnic cuisines do not recognize as a threat to the development of cittaslow movement, is another important findings of this study.
\end{abstract}

Key words: Slow food, Cittaslow, Gastronomic tourism, Seferihisar, İzmir, Turkey.

\section{Introduction}

Adequate and balanced feeding is one of the basic and probably the most important conditions of society and its constituent individuals to live healthy, for economic and social development of them and for sustaining a peaceful and secure existence (DPT, 2003). As stated in Maslow's hierarchy of needs pyramid, food and beverage needs are one of the most essential necessaries necessities of individuals to sustain their lives (Aymankuy \& Sarığlan, 2007).

During the historical process, every society has developed its own cuisine, diversified it and created a unique taste. However, the effect of globalization has made the society's conceptions of the traditional feeding to be destroyed and to be forgotten. Intensive work caused to cut down the time allocated to feeding and made the food only a physical need instead of being a social phenom-

\footnotetext{
* Pamukkale University, Faculty of Tourism, Denizli, Turkey

** Gazi University, Faculty of Tourism, Gölbaşı-Ankara/Turkey; Corresponding Author: yukselozturk66@gmail.com, oyuksel@gazi.edu.tr
} 
enon. The concept of fast food feeding as a product of globalization is another factor that accelerates the oblivion process of the traditional dietary habits and local cuisine. Especially the international chains of fast food brands from around the world are in an effort to pervade the precept of monotype feeding. The process of feeding habits standardization leads to cultural standardization, therefore, leads to the people standardization. To avoid people from the negative effects of globalization and to protect the cultural values, the various response groups in national and international scale have been formed for searching solutions by coming together. Slow food and cittaslow movements are among the most common and effective formations which is said. As it was said, in many studies that has been previously done regarding to the development and philosophy of slow food movement (Miele \& Murdoch 2002; Labelle 2004; Laudan 2004; Meneley 2004; Donati 2OO5; Weiner, 2005; Walter, 2009; Chi, 2OIO; Günerhan et al. 2OIO; Mayer \& Knox, 2OIO), slow food movement as opposed to uniformization of societies' feeding habits, it adopts the philosophy of "good, clean and fair food" for everyone.

The Cittaslow movement aims to protect traditional and natural feeding habits of slow food movement to encourage the use of local food products, to draw attention to the disadvantage of fast food feeding and to move the sustainable use of natural resource philosophy to the urban dimension. Especially, the registered dwelling unit as cittaslow, is a remarkable destination for cultural tourists. On the other hand, it is possible to say that slow cities are destinations for natural gastronomy tourism. Because the philosophy of slow food and Cittaslow exactly coincides with the philosophy of gastronomy tourism. From this point, the basic aim of the study is to analyze the reflections of cittaslow movement on the local and the other ethnic cuisine and on the local food and beverage prices. The study was shaped according to the assessments of the first cittaslow's residents in Turkey, Seferihisar town of İzmir, on the subject.

\section{Literature Review}

\section{Slow Food and Cittaslow Movement}

Slow food movement, was born as a reaction of many icons of globalization against the hegemony and it has a cultural barricade property. Slow food movement which has been started in reaction to a McDonald's restaurant, wanted to be opened in the city center of Rome, near the historic Spanish steps (Reiger, 2004), has aimed at protection of traditional foods and production methods, transmission of local plant and animal species to future generations. This movement was started by small groups constituted of gastronomic writers and cuisine chefs, in 1986, in a small town, named Bra, located in the Piedmont region in northern Italy.

Slow food movement for centuries has become a resistance symbol of mankinds' traditional delicacies, that passing through the filter of the culture, against the cola and hamburger also it has been adopted by spreading around the world in the short time. But the slow food movement has advocated objects which are beyond the above-mentioned objects, not only the satiation, getting a taste of food is a human right.

Cittaslow consists of città (city) word in the Italian and slow word in English; it has been used in a sense of the quiet city. Cittaslow is a non-governmental organization (NGO), it emerged from the slow food movement in order to for standardization of globalization, cities and city residents and preventing of lifestyles' local characteristics that are forgotten. It is the association that towns and cities participated in because they do not want to be one of homogenous places, created by globalization; they want to take place in the world stage while protect- 
ing their local identity and characteristics. The Cittaslow movement emerged in I999 towards the vision of Paolo Saturnini who was the former head of the Chianti municipality in Greve. Paolo Saturnine had carried the idea of the cities' assessments by themselves and different development model to the national dimension in order to improve the quality of life. His ideals, in short time, have been adopted by the mayors of Bra (Francesco Guida), Orvieto (Stefano Cimicchi), Positano (Domenico Marroni) and slow food president Carlo Petrini (www. cittaslowseferihisar.org). According to the 2014 (January) data; the Cittaslow movement has a wide network, consisted of I79 members of city and town from 28 different countries.

To be a member of cittaslow network, the city population must be less than 50,000 and must carry out at least 50\% of the criteria given by cittaslow association. The criterion has been continuously controlled to see that cities which are the member of association in advancing process, protecting or not protecting these criteria.

Criteria headings that has been foreseen, listed as below; environmental policies (II units), infrastructure policies (I3 units), technologies and facilities for the urban quality (9 units), to protect domestic production (II units), hospitality (5 units), awareness (3 units), support of slow food activities and projects (7 units).

Slow food and cittaslow philosophy do not only aim to generalize the healthy and natural feeding or to protect the traditional feeding habits and the natural structure, also, they aim to organize against a precept that is big fish eating little fish which is in the global economic system. The basis of the movement comprises of the survival of local farmers and other food producers that cannot afford to compete with brands of fast food, providing services on an international scale.

\section{Local Cuisine and Gastronomy Tourism}

When cuisine is mentioned, it is not only a food and beverage of a nation's cuisine, at the same time, it is required to describe the preparation of these foods and beverage and their service methods, tools and materials used in service, cuisine's location and architecture, food ceremonies and similar activities (Ciğerim, 1999). Davis and McBride (2008) has defined cuisine, "is an expression method form of culture such as sculpture or dance ".

On the other hand, for thousands of years people, who travel, must meet the needs of accommodation and foods during they are away from home. Therefore, the history of food and beverage businesses, such as history of accommodation businesses has a very long background. The emergence of the inns in the west and the caravanserais in the east, in the I3th century, were formed the basis for hotels and food and beverage businesses (Koçak, 1997). However, the necessaries for eating and drinking rather than just a physical need, such as Göktan (2000) pointed out, is to attract people's interest with gastronomic activities like traditional clothes, traditional cuisine materials, containers, leaks, cooking methods and techniques. Because food culture which has consisted of the essential elements such as the lifestyle of each society and sense of taste, passed from generation to generation for hundreds of years and it has become the representative of that culture.

Studies which have been done for determination of the new tourists' profile in the world shows that the tourists were interested in the country's cuisine as same well as that countries historical and touristic places. Cultural tourists travel to taste different flavors as well as to see the different places (Yenen, 2007). The interest to the cuisine and wine-themed tourism in global scale has increased in recent years and this increase has been expected to continue (Deneault, 2002). 
Food can play an important role in differentiating touristic destination from the others. Branding of cuisine according to the nations (Chinese, French, Italian, Turkish, Mexican, etc.) has led to a positive relationship between food and destinations (Okumuş et al. 2007).

Do people travel to taste the new flavors they want or do they taste different flavors at their home to feel themselves like they are traveling? No matter what is the answer is, there is a high relationship between food and tourism. The concurrence between food and tourism has been defined as cuisine - gastronomic tourism (Molz, 2007). Gastronomy tourism has provided a significantly contribution to the sustainability of tourism. This contribution will extend with increase of leisure types such as; cuisine, wine, cooking and farm-themed holiday (Barkat \& Vermignon, 2006). The term of gastronomy tourism was first used by Long (2004) in I998 in order to recognize the other cultures with dimension of food and wine. Wolf (2OO2) was defined cuisine and gastronomy tourism as "food and beverage research, enjoying fully and traveling for the purpose of obtaining unforgettable gastronomic experience" (Kivela \& Crotts, 2006).

Salvador Dali was said that "if beauty was not defeated it does not mean anything". Indeed, in terms of tourist attractions items, some cafes, bars and restaurants, providing services, in Rome and Paris are important value as well as the Colosseum and the Louvre. The local cuisine of Tuscany and Provence, cities attracts millions of tourists over and over again to these popular destinations (Fox, 2007). The Canadian Tourism Commission described gastronomy tourism as an important component of cultural tourism, which is developing very fast. On the other hand, in 2002, strategy towards the development of activities related to wine and culinary tourism, developed by the Tasmania Tourism Association has given results in a little while and it has been shown increase in amount of tourist expenditure per capita along with their overnight period (Shenoy, 2005). Slow food and cittaslow movements with its philosophy, which was aimed to protect and present the traditional cuisine, to support the local producers, to protect the forgotten plant and animal species diversity, has accelerated the development of gastronomy tourism.

\section{Method}

\section{Object of Study}

Cittaslow movement was born with philosophy of protection of cultural values, natural environment, lifestyle and traditional feeding habits. Cittaslow philosophy is an interesting subject that to what extent is effective in cities and towns, including the network of cittaslows. Accordingly, the main aim of the study is to analyze the effect of the projects and activities related to the slow food dimension of cittaslow movement, on the local cuisine, the ethnic cuisine and the prices of food and beverage industry. For this object, try to answer the following questions;

I. What is the level of participants' assessments towards the gastronomic effect of Cittaslow movement?

2. Do the participants' assessments towards the gastronomic effect of cittaslow movement vary according to their demographic characteristics?

3. Within the scope of the movement of cittaslow, is there a significant difference between the participants' assessments towards the factors that affect the gastronomy? 


\section{Data Collection and Analysis}

In the study, the questionnaire method was used for data collection. This questionnaire form was developed according to the slow food criteria of cittaslow movement. In the first part of the questionnaire, formed from two parts, 7 questions concerning to the individual characteristics of participants were given. In the second part of it, the I9 closed-ended questions related to the effect of the slow food movement on, local cuisine and city residents (I3), prices of food and beverage industry (3) and other ethnic cuisines (3) were given. In addition, in the questionnaire form, the open-ended question towards the different assessments of the participants about the subject was given. Participation level in each expression, that were in the second part of the questionnaire, was graded according to the 5-point Likert-type scale ( $\mathrm{I}=$ strongly disagree, 2 = less agree, 3 = moderately agree, 4 = agree, 5 = strongly agree).

In addition, as results of the "One way analysis of variance for independent samples (ANOVA)", for the variables that significantly vary among themselves, "Multiple comparison (Tukey HSD) test" was done to identify this difference between which ones have occurred. As a result of "One-Way Analysis of Variance for relevant sample (ANOVA)", for the variables that significantly vary among themselves, "Multiple comparison (Bonferroni) test "was done to determine this difference between which ones have occurred. Related to the reflection of Cittaslow gastronomic movement, reliability (Cronbach's Alpha) and factor analysis were applied to the questionnaire.

\section{Research Findings}

Within the framework of the study, $53.5 \%$ of participants were female, $46.5 \%$ of them were male. By examining the age distribution of participants, it was observed that the rate of the 36-50 years of old was $36.4 \%, 25$ and under 25 years of old was $32.6 \%$. It was understood that $5 \mathrm{I} .7 \%$ of the participants were married, $48.3 \%$ of them were single, $28.7 \%$ of them were in secondary school and $20.4 \%$ of them had a graduate degree. By examining the occupational distribution of the participants, it was found that $25.6 \%$ of participants were the public health workers, $19.4 \%$ of them were students. In terms of their income levels, monthly income of a large majority, 36,7\%, were 700 TL (Turkish Lira). On the other hand, 4I.3\% of the participants were eating I-2 times per month at outside, $37 \%$ of them were not eating any food at the outside.

The reliability coefficient (Cronbach's Alpha) related to the slow city movement's effects on "the local cuisine and the conscious of feeding" was calculated as $\alpha=0.93$, the effects on "the prices of food and beverage sector" was calculated as a= 0.75 and the effects on "the other ethnic cuisines" was calculated as $\alpha=0.72$ (Table I).

Table 1. Total Variance and Reliability Coefficients of Questionnaire that Explained Related To The Gastronomic Reflections of Being Seferihisar as a Cittaslow

\begin{tabular}{|l|r|r|r|}
\hline Factors & \multicolumn{1}{|c|}{$\begin{array}{c}\text { Rate of variance } \\
\text { explanation }\end{array}$} & $\begin{array}{c}\text { Cumulative } \\
\text { Variance }\end{array}$ & $\begin{array}{c}\text { Reliability coefficient } \\
(\alpha)\end{array}$ \\
\hline $\begin{array}{l}\text { The effects on the local cuisine and the } \\
\text { conscious of feeding }\end{array}$ & $38,99 \%$ & $38,99 \%$ & 0,93 \\
\hline $\begin{array}{l}\text { The effects on the prices of food and } \\
\text { beverage sector }\end{array}$ & $13,45 \%$ & $52,44 \%$ & 0,75 \\
\hline The effects on the other ethnic cuisines & $9,34 \%$ & $61,78 \%$ & 0,72 \\
\hline
\end{tabular}


Three factors (dimension), collected from the I9 expressions of questionnaire, related to the gastronomic effects of being Seferihisar as a slow city, explain the 6I.78 percent of total variability. The dimension of "the effects on the local cuisine and the conscious of feeding" is the factor that describing the variability in the highest rate (38.99\%), "the effects on the other ethnic cuisines" is a factor that describing the variability in the lowest rate (9.34\%).

According to the findings concerning to the effect of being Seferihisar as a "cittaslow" on the local cuisine are given in Table 2 , it has been seen that the average for each expression was above 3 as a median. It has been seen that the standard deviation values, especially for the dimension of "the effects on the local cuisine and the consciousness of feeding" (the first I3 expressions), was around I. The standard deviation values of the participants' opinions towards the factor of "the effects on the local cuisine and the consciousness of feeding "did not show a lot of distribution. It can be said that their assessments toward the factors of "the effect on the price of food and beverage sector" and "the effects on the other cuisine" showed a wider distribution.

According to the findings, participants' opinion toward the expression of "the effects on the local cuisine and the consciousness of feeding" showed the distribution in the range of $\bar{x}$ $\overline{\mathrm{X}}=4.03-\overline{\mathrm{X}}=4.42$. The most positive opinions, according to the participants' assessments, were "being Seferihisar as the slow city is an opportunity to introduce the traditional cuisine of the city to the visitors" $(\overline{\mathrm{x}}=4,42)$ and "being Seferihisar as a cittaslow is an opportunity for survival of plants and seeds, peculiar to the region and used to make traditional foods" $(\overline{\mathrm{x}}=4.33)$. The average level of $4 . \mathrm{I} 7$ for the expression of "being Seferihisar as a cittaslow is an opportunity for city to organize local culinary -themed tours in it" can be interpreted in accordance with the cittaslow movement is an effective step to develop the gastronomy tourism in Seferihisar.

On the other hand, the average concerning to the expression of "being Seferihisar as cittaslow is an opportunity for farmers to accelerate the transition to organic agriculture," was 4.I2, concerning to the expression of" being Seferihisar as cittaslow is an opportunity for local food producers to get value for their effort" was 4, 22 and towards the expression of "being Seferihisar as a cittaslow is an opportunity for city residents to gain their awareness of the consumption of foodstuffs, produced in the region," was 4.IO. The figures show that local producers and consumers of cittaslow Seferihisar agree about the philosophy of slow food that is "good, clean and fair" food production and consumption.

According to the findings in Table 2, it has been understood that there is a significant difference with respect to the results of Bonferroni test $(p<O$.OI) that the participants' opinions due to the dimension of "the effects on the local cuisine and conscious feeding", "the effects on the prices of food and beverage sector" and "the effects on the other ethnic cuisines". By examining averages of dimensions, while the most positive dimension about the participants' opinion is $(\overline{\mathrm{x}}=4 . \mathrm{I} 8)$ "the effects on the local cuisine and conscious feeding", the most negative dimension about the participants' opinion is $(\overline{\mathrm{x}}=3 . \mathrm{I7})$ "the effects on the prices of food and beverage sector".

Table 2. The Comparison of Factors Related to the Gastronomic Reflections of Cittaslow Movement

\begin{tabular}{|l|r|r|r|}
\hline Factors & $\bar{x}$ & s.d. & P \\
\hline The effects on the local cuisine and conscious feeding & $4,18(\mathrm{a})$ & 0,69 & \\
\cline { 1 - 2 } The effects on the prices of food and beverage sector & $3,17(\mathrm{~b})$ & 1,13 & \multirow{2}{*}{0,00} \\
\hline The effects on the other ethnic cuisines & $3,42(\mathrm{c})$ & 1,11 & \\
\hline
\end{tabular}

$p<0,01 a, b, c$ : There is a significant difference between dimensions with different letters. 
It is seemed that being Seferihisar as a cittaslow, that has considerable effect on the local cuisine. It is understood that cittaslow movement has objects towards the local cuisine such as; protection of traditional foods, introducing to the visitors, passing to the future generations, pervading of the local and organic food consumption, is effective in Seferihisar. However, besides these positive developments, the cittaslow movement has caused to an increase in the prices of food and beverage sector. It can be said that this development has been originated from the changes in the balance of supply and demand. Increase in demand for the local production of foodstuffs has led to price increases. Indeed, in this respect, Mayer and Knox (2OIO) indicated that people, who are living in metropolitan cities, will want to have the second house in cittaslows and this would lead to an increase in other prices.

On the other hand, it is remarkable that participants' opinion $(\overline{\mathrm{x}}=3.42)$ due to the statement that setting up of the businesses that presenting of the foods belongs to the different regions and countries' cuisine in Seferihisar, is not a threat to cittaslow movement. This finding can be interpreted in accordance with "the protection and promotion of local cuisine, does not require the exclusion of other ethnic cuisines". This sentence is very important to set forth the positive thoughts of Seferihisar people due to the other cultures. Because the philosophy of cittaslow does not advocate the exclusion of another culture, it advocates the removal of the local culture. Regarding to the subject, according to the Donadio (2009: I3), in the city of Lucca, located in Tuscana of Italy, the city council did not give permission to an entrepreneur who wanted to open a kebab restaurant with reason of "it would distort the local culture and historical identity". A case against the city council that was accused of racism was opened and the subject caused discussions in multicultural Europe where the global economy prevailed in there. As seen in Table 3, the participants' assessments towards the effect of cittaslow movement on the local cuisine, has seemed to have a significant difference according to their gender.

Table 3. The Comparison of Participants' Assessments Towards The Effects of Their Gender and the Cittaslow Movement on The Local Cuisine

\begin{tabular}{|l|r|r|r|r|r|}
\hline Gender & $\mathrm{n}$ & $\overline{\mathrm{x}}$ & \multicolumn{1}{c|}{ s.d. } & \multicolumn{1}{c|}{$\mathrm{t}$} \\
\hline Female & 207 & 4,28 & 0,70 & \multirow{2}{*}{0,79} & 0,00 \\
\hline Male & 180 & 4,08 & 0,67 & & \\
\hline
\end{tabular}

$p<0,05$ There are significant differences between groups $(p<0,05)$.

Towards the effects of the cittaslow movement, the females participants' assessments $(\overline{\mathrm{x}}=$ 4.28), were more positive that the male participants' assessments $(\overline{\mathrm{x}}=4 . \mathrm{O} 8)$. However, being the average of each of the two groups upon 4 points indicated that gastronomic effect of this movement was how effectively. The participants' assessments towards the factor of the cittaslow movement's effect on the other ethnic cuisines, to see if there is differences according to the educational status or not, are given in Table 4, to see if there is differences according to their age or not, are given in Table 5. As it can be seen in Table 4, there is no significant difference between the assessments towards the effect of the cittaslow movement and the educational status of participants on the other ethnic cuisines.

The assessments towards respondents with different educational level and the other ethnic cuisines, has no effect on the cittaslow movement in Seferihisar, distributed in the range between $\overline{\mathrm{x}}=3 . \mathrm{I5}$ to $\overline{\mathrm{x}}=3.83$. Not perceiving of other ethnic cuisines, offering the service, as a threat, is remarkable as well as very important for the sustainability of the local cuisine in Seferihisar. Because the cittaslow philosophy advocates the public awareness for the pro- 
Table 4. The Comparison of Assessments Towards the Participants' Educational Status and the Factor of the Other Ethnic Cuisines Effects on the Comparison of Assessments

\begin{tabular}{|c|c|c|c|c|}
\hline Educational Status of Participation & $n$ & $\overline{\bar{x}}$ & s.d. & $P$ \\
\hline Primary school & 65 & 3,55 & 1,07 & \multirow{6}{*}{0,20} \\
\hline Secondary school & 111 & 3,56 & 1,03 & \\
\hline High school & 84 & 3,34 & 1,15 & \\
\hline Undergraduate & 40 & 3,15 & 1,39 & \\
\hline Associate degree & 79 & 3,29 & 1,06 & \\
\hline Postgraduate & 8 & 3,83 & 0,53 & \\
\hline
\end{tabular}

$p>0,05:$ There is no significant difference between the dimensions.

tection of the local cuisine and its components. In this respect, it aims to raise residents and visitors of the city's awareness about sociological, economic and biological reflection of feeding with foods that made by local, organic and traditional methods. However, this objective does not require seeing the other ethnic cuisines as a potential risk. Research findings indicate that the people of Seferihisar got the message significantly correct and focused on their own cultural values. There is no significant difference between the participants' age and their assessments towards the effect of the cittaslow movement on the other ethnic cuisines, was seen in Table 5 .

Table 5. The comparison of Assessments Towards the participants' Age with Factor of the Slow City Movement Effects on the Other Ethnic Cuisines

\begin{tabular}{|l|r|r|r|r|}
\hline Educational statue & $\mathrm{n}$ & $\bar{x}$ & \multicolumn{1}{c|}{ s.d. } & \multicolumn{1}{c|}{$\mathrm{P}$} \\
\hline 25 and under 25 years old & 126 & 3,50 & 0,94 & \\
\cline { 1 - 3 } 26 -35 years old & 64 & 3,14 & 1,22 & 0,08 \\
\hline $36-50$ years old & 141 & 3,40 & 1,20 & \\
\cline { 1 - 3 } 51 and over 51 years old & 56 & 3,62 & 1,02 & \\
\hline
\end{tabular}

$p>0,05:$ There is no significant difference between the dimensions.

The averages of young- elderly Seferihisar participants' evaluation towards the other ethnic cuisines distributed between 3.I4 up to 3.62. Regarding to the subject, it is remarkable that the averages of the participants' evaluation, who were 5 I years and above, $(\overline{\mathrm{x}}=3.62)$, is higher than the other participants' ones. This result is important in respect to emphasize on tolerance and cultural self-confidence of young - the elderly Anatolian people.

\section{Conclusions}

In this study, the effect of the gastronomic dimension of cittaslow movement, aims at the protection of cities in cultural, environmental and economic sense, has been evaluated in accordance with the opinions of Seferihisar residents, as the first representative of the slow city in Turkey. Research findings, shows that two years' experience of Seferihisar as a cittaslow, has been reflected positively on the local cuisine. It seems that it is very common that in the town, the cittaslow movement has been considerably adopted and the movement was the opportunity for protection and promotion of local cuisine. It is effective in raising the city 
residents (especially students) awareness about disadvantages of fast food-style feeding and the advantages of feeding that produced by local, organic and traditional methods.

Among the opportunities offered by the cittaslow movement for the farmers of Seferihisar there are acceleration of the process of transition to organic farming, production by natural methods and in season and directly selling of products to consumers at the village markets, without the need for the agent. Regarding to the subject, the vegetable gardens, created for students at primary schools has been very effective in raising their awareness towards the production of vegetables by nature, soil and natural methods.

The events related to the slow food dimension of the cittaslow philosophy constitute the substructure of alternative tourism types such as; gastronomy and wine tourism. Therefore, cittaslow are registered destination for gastronomic and wine tourism. Thus, the assessments of participants towards the expression of "Being Seferihisar as a cittaslow is an opportunity for city to organize local culinary -themed tours in it" was realized at the level of $\bar{x}=4 \cdot \mathrm{I} 7$.

The cittaslow movement brings the many advantages to the city, as well as, it brings various disadvantages. Seferihisar after getting the right to be a cittaslow in November 2009, it has gained popularity in both national and international scales. The increase of interest in the city has led to increase of town population at record levels.

On the other hand, branding of the city with the patent of the cittaslow has caused an increase in the prices of food and beverage sector. Indeed, the average $(\overline{\mathrm{x}}=3.06)$ of expression regarding to "I think that being Seferihisar as a cittaslow did not cause an increase in the prices of foodstuffs, which are local production" showed that this expression is the most negative one among the other statements in the questionnaire. As stated above, it is clear that being Seferihisar as a cittaslow has the positive effect related to the gastronomy as well as, it is an important opportunity for the city's promotion and local development. On the other hand, it is important to develop short and long term projects for the prevention of unplanned construction, caused by excessive population growth.

\section{References}

Aymankuy, Y., \& Sarığlan, M. (2007). Yiyecek-içecek felsefesi ve beslenme alışkanlığının geliştirilmesine yönelik bir model önerisi. Paper presented at the Ith National Gastronomy Symposium \& Artistic Activities, Antalya, Turkey.

Barkat, S., M., \& Vermignon, V. (2006). Gastronomy tourism: A comparative study of two French regions : Brittany and la martinique. Paper presented at Sustainable Tourism with Special Reference to Islands and Small States Conference, Malta.

Chi, J. (2OIO). Slow Food and the Network Approach to Development. Journal of International Service,I9(2), 83-97.

Ciğerim, N. (I999). Kapadokya yöresi mutfağı. In Proceedings of 2000'li Yıllara Girerken Kapadokya'nın Turizm Değerlerine Yeniden Bir Bakış Hafta Sonu Semineri VI, Nevşehir, Turkey.

Davis, M., \& McBride, A. (2008). The state of American cuisine. A White Paper Issued by the James Beard Foundation Based on Surveys Conducted as Part of the 2007 James Beard Foundation's Taste America National Food Festival.

Deneault, M. (20O2). Acquiring a taste for cuisine tourism. Ontario: A Product Development Strategy, Ottava. 
Donadio, R. (2009). A Walled City in Tuscany Clings to Its Ancient Menu'. The New York Times. Retrieved February I6, 2OII, from http://www.nytimes.com/2009/03/I3/world/ europe/I3 lucca. html.

Donati, K. (2005). The pleasure of diversity in slow food's ethics of taste. Food, Culture and Society, 8, 227-242.

DPT. (2OO3). Ulusal gııda ve eylem planı I. aşama çalışması. Ulusal gıda ve beslenme stratejisi çalışma grubu raporu. No: 2670, Ankara, Turkey

Fox, R. (2007). Reinventing the gastronomic identity of Croatian tourist destinations. Hospitality Management, 26, 546-559.

Göktan, H. B. (2000). Osmanlı Mutfağı. Şekerbank Yayınları, İstanbul, Turkey.

Günerhan, A. S., Erdem, Ü., \& Günerhan H. (2OIO). Çevre ve Enerji Açısından Yavaş Şehir Hareketinin Gelişimi. Retrieved January I2, 2OII, from http://www.mmo.org.tr/resimler/ dosya_ekler/92ea 5eb97cbf5If_ek.pdf? dergi=IO45.

http://www.cittaslowseferihisar.org/index.php?option=com_content\&view=article\&id=64\&Itemid=63. Retrieved February IO, $20 I$.

http://www.seferihisar.bel.tr/index.php? view=article\&id=4O2\%3Akoypazari\&format=pdf\&option=com_content\&Itemid=4O2. Retrieved February OI, 2 OII.

http://www.slowfood.com/international/2/our-philosophy. Retrieved February I4, 2 OII.

http://www.slowfood.com/international/4/where-we-are\#risultati. Retrieved February 23, $2 \mathrm{OII}$.

http://www.slowfood.com/international/8/abc-of-slow-food?session=query_session: B 2 F5B I42O9caf33B63XPq3I563E3. Retrieved March 09, 2 OII.

http://www.yerelgundem.com/haberler/273II7/seferihisarin_nufusu_artti.html. Retrieved February I2, 2OII.

Kivela, J., \& Crotts, J. (2006). Tourism and gastronomy: gastronomy's influence on how tourists experience a destination. Jornal of Hospitality \& Tourism Research 30 (3), 354-377.

Koçak, N. (1997). Yiyecek içecek işletmelerinde toplam kalite yönetimi, Unpublished PHD thesis, University of Dokuz Eylül, Izmir, Turkey.

Labelle, J. (20O4). A recipe for connectedness: bridging production and consumption with slow food. Food, Culture and Society 7 (2), 8I-96.

Laudan, R. (2004). Slow food, the French terroir strategy, and culinary modernism: an essay review. Food, Culture and Society 7 (2), I33-I49.

Long, L. M. (2004). Culinary Tourism. University Press of Kentucky, Lexington.

Mayer, H., \& Knox, P. (2OIO). Small-town sustainability: prospects in the second modernity', European Planning Studies I8 (IO), I545-I565.

Meneley, A. (2004). Extra virgin olive oil and slow food. Anthropologica 46 (2), I65-I76.

Miele, M., \& Murdoch, J. (2OO2). The practical aesthetics of traditional cuisines: slow food in Tuscany. Sociologia Ruralis 42 (4), 3I2-328.

Molz, J. G. (2007). Eating difference: the cosmopolitan mobilities of culinary tourism. Space and Culture IO (I), 77-93.

Okumuş, B., Okumuş, F., \& McKercher, B. (2007). Incorporating local and international cuisines in the marketing of tourism destinations: the cases of Hong Kong and Turkey. Tourism Management 28, 253-26I.

Öztürk, Y. \& Görkem, O. (2OII). Cittaslow Hareketinin Yerel Mutfağa Etkileri: Seferihisar Örneği. Paper presented at the 5th National Gastronomy Symposium \& Artistic Activities, Antalya, Turkey. 
Reiger S. R. (2004). In the spirit of Noah, food iversity and the slow food movement. The Canadian Organic Grower, Fall 2OO4, pp. IO-I5. Retrieved February 24, 2OII, from http:// www.cog.ca/documents/ Slow Food.pdf.

SB (Seferihisar Belediyesi). (2OIO). Sakin Şehir Seferihisar. Tanıtım Serisi: 3. Retrieved January 09, 2OII, from http://webdeyim.net/tr/e_ kitap/seferihisar-belediyesi/seferihisar-tanitimserisi /3/I.

Shenoy, S., S. (2005). Food tourism and the culinary tourist. Unpublished PHD thesis, University of Clemson, Clemson.

Walter, L. (2009). Slow food and home cooking: toward a relational easthetic of food and relational etic of home. The Journal of The Center For Food in Community and Culture, I, I-23.

Weiner, S. (2005). Slow Food. Centro Stampa, Bra.

Wolf, E. (2OO2). Culinary tourism: a tasty economic proposition. Retrieved January 2O, 2OII, from http://www.culinarytourism.org.

Yenen, Ş. (2007). Türk mutfağı ve turizm. Akşam. Retrieved January 24, 2OII, from http:// www.aksam. com. tr/ yazar.asp? a=39396,IO,I3O. 